\title{
Nursing assistance in encephal death protocol
}

\begin{abstract}
Introduction: The nurse's role in assisting the potential organ donor is essential throughout the process of organ donation and confirmation, thus becoming essential knowledge about this subject.
\end{abstract}

Objective: to identify priority nursing care in the maintenance of organ donors and in this direction to bring to reflection the importance of nurses' work in ME protocol.

Method: This is a bibliographical review of the literature. Scientific articles were searched in the Scielo databases between July and August 2017

Results: 110 scientific articles were found that approached the chosen theme, of which 14 articles were selected. Based on the analysis performed in this research, two major categories emerged: Nursing care centered on the operationalization of the ME Protocol and family approach and Nursing Care in the maintenance of the organ donor potential.

Conclusion: during this process it was possible to evidence the care related to the whole process of finding, maintaining and donating organs for transplants. In order to enable strategies to optimize the procurement of organs and tissues for transplantation.
Volume 5 Issue 2 - 2018

\author{
Fernando Riegel,' Desiree Magdalena \\ Quintana $^{2}$ \\ 'Doctor of Nursing, Serviço de Enfermagem Cirúrgica do \\ Hospital de Clínicas de Porto Alegre, Brazil \\ ${ }^{2}$ Academic Nursing of Centro Universitário FADERGS, Brazil
}

Correspondence: Fernando Riegel, Doctor of Nursing, Serviço de Enfermagem Cirúrgica do Hospital de Clínicas de Porto Alegre, Brazil, Email friegel@hcpa.edu.br

Received: February 22, 2018 | Published: March 14, 2018

Keywords: brain death, organ donation, organ donor, nursing team

\section{Introduction}

Transplantation of organs or tissues is characterized as the transfer of living cells, tissues or organs, for the purpose of restoring a function, and it may happen between a person who has recently been found to have brain death (a cadaver donor) or a voluntary donor (living donor) to a living person, recipient. ${ }^{1}$ Transplantation is an effective and safe therapeutic method in the treatment of various pathologies that cause deficiencies or failures of various organs and tissues, such as heart or kidney failure, promoting improvement, quality and life expectancy of people who are carriers of these diseases, providing a healthy organ for the possible stabilization of these pathologies. ${ }^{2}$

Brazil is the second country in number of organ transplants performed each year, with more than $90 \%$ being performed by the Unified Health System (SUS). Living donors can donate bone marrow, one of the kidneys, part of the liver and part of the lung. The non-living donor (cadaver) can donate the heart, lungs, kidneys, skin, liver, pancreas, intestine, and bones and tissues such as corneas, skin, heart valves, tendons, veins. Although the issue of organ donation has evolved constantly, the absence of notification of brain death causes errors during the maintenance and abstraction of the organs, becoming evident factors and impeding the donation, thus importance of the qualification of the health professionals involved in the process of capture and donation. ${ }^{3,4}$

Brain death in Brazil is characterized by the irreversible stoppage of brain functions, ie cerebral cortex, telencephalon, and brainstem. Therefore, patients who present a nonreactive and nonresponsive coma of known and irreversible cause will need to undergo clinical exams in order to identify the absence of brain activity. ${ }^{5}$ The diagnosis of brain death is defined after performing two clinical exams by two different physicians who have no connection with the transplant team. In Brazil it is mandatory to perform a complementary exam demonstrating the electrical, metabolic or brain perfusion inactivation. Clinical exams should be performed at intervals of at least six hours for adults. ${ }^{6}$

To be an effective donor will depend on the exclusion of diagnosed diseases such as: renal, hepatic, cardiac, pulmonary, pancreatic and spinal failure; malignant tumors, human immunodeficiency virus (HIV), viral hepatitis, active sepsis, tuberculosis, autoimmune disease, use of illicit injectable drugs, among others. ${ }^{7}$ When the diagnosis of brain death is established, communication is made to the transplant center, and immediately the family must be informed and guided about the organ donation process by the professionals responsible for organ donor recruitment. ${ }^{8}$

By becoming an effective donor, the care process starts at the intensive care unit or in the emergency room, requiring a multiprofessional team that is qualified and prepared for the maintenance of the potential donor in both the scientific and the humanistic fields. ${ }^{2}$ Maintaining the potential organ and tissue donor is essential as soon as a brain death is diagnosed. The health professional must be aware of the reversion of the death rate, promoting the utilization of organs for donation and transplantation. The conduct of professionals is essential in maintaining the body, maintaining the body in hemodynamic conditions, until the organ donation is legally concluded. $^{9}$

The maintenance of the potential donor already in encephalic death begins with the regulation of the circulatory and metabolic state of the body, evaluating the state and function of each organ, in order to enable the largest number of healthy organs for transplantation and to guarantee graft quality. ${ }^{10}$ The Federal Nursing Council (COFEN) determines that nursing care is essential to the potential donor in order to enable the organs for transplantation. The nurse should be able to plan, perform, coordinate, supervise and evaluate the nursing care provided to the organ and tissue donor, as well as provide support to the family members. The nurse performs her role collectively with other professionals of the health team, promoting the care and assistance of the sick person.

The justification for choosing this theme is due to the fact that organ donation, as well as transplantation, require constant discussion in order to clarify and take information to the community in order to improve organ donation processes and thereby save countless lives that are waiting in line for transplants, in this context the nurse's role in assisting the potential organ donor is essential, throughout 
the whole process, making it essential for this professional to know about this subject. Therefore, this study aims to identify priority nursing care in the maintenance of organ donors and in this direction to bring to reflection the importance of nurses' work in ME Protocol. This study proposes to answer the following research question: what are the priority nursing care for maintenance of organ donors in the protocol of encephalic death?

\section{Method}

This is a bibliographical review of the literature that is characterized by the clarification of research gaps through a detailed analysis in scientific papers. It consists basically of books and scientific articles. ${ }^{11}$ The sample of this study was composed by 14 scientific articles and 2 books on the nursing assistance theme to the potential organ donor in brain death. As inclusion criteria were used: original articles and chapters of books published between the years 2011 to 2017, available in full free access and in Portuguese, The search for articles was carried out only in the database: SciELO (Scientific Electronic Library Online ). The descriptors in Health Sciences (DeCS) used were: brain death; organ donation; organ donor; Nursing team; encephalic death. Exclusion criteria were articles published in a foreign language and from other countries, articles that did not respond to the guiding question of this study. Data collection occurred between July and August 2017. After the data collection, the exploratory reading of the material was started, followed by the reading of the article summary to identify the contents of the article, thus giving an overview of the work. The analysis of the data was carried out through the thematic one that consists of three stages: Pre-analysis, material exploration, data processing and interpretation.

The phase of the pre-analysis consisted in the choice of the material to be analyzed; in the resumption of the research question and the initial objective of the research, reformulating them in front of the material collected. This phase was organized by the floating reading and organization of the corpus. The material exploration phase consisted mainly of the material coding operation. Firstly, each text was cut into thematic units after classifying and aggregating the data, choosing the empirical categories that command the specification of the themes. The data processing and interpretation corresponds to the final phase, and it was sought to articulate the content of the selected articles with the literature review to identify the content underlying what was identified in the publications. ${ }^{12}$

The ethical considerations regarding the preparation of literature reviews were respected, so as to ensure authorship of the articles used, as well as the authenticity of ideas, concepts and definitions of the authors, with the purpose of preserving the copyright and respecting Law no. 9,610 / 98 of February 19, 1998..$^{13}$

\section{Results}

The search strategies of the selected articles are presented below Table 1.

After searching the selected database, 110 articles were found and 14 articles were selected after analysis and observation of the inclusion criteria of this study. The following is the characterization of the sample of this study, highlighting the database, the status, title, authors and publication period of the analyzed publications respectively (Table 2).

Table I Search strategies for articles

\begin{tabular}{llll}
\hline Data base & Descriptors & Found & Selected \\
\hline SCIELO & "Organ donation" and Nursing & 25 & 5 \\
& "Doador de órgãos" and Maintenance & 12 & 2 \\
& "Staff of nursing" and Brain Death & 6 & 1 \\
& "Brain Death" and Nursing & 17 & 3 \\
& "Brain Death" and Manutenção & 9 & 2 \\
Total & Brain Death & 41 & 1 \\
& & 110 & 14
\end{tabular}

Table 2 Characterization of the sample

\begin{tabular}{|c|c|c|c|c|c|}
\hline Code & $\begin{array}{l}\text { Data } \\
\text { base }\end{array}$ & $\begin{array}{l}\text { Country/ } \\
\text { State }\end{array}$ & Title & Authors & Journal, Year, Vol, pages \\
\hline A1 & SCIELO & Brazil/SC & $\begin{array}{l}\text { Guidelines for evaluation and validation of } \\
\text { potential organ donors in brain death }{ }^{14}\end{array}$ & Glauco, Adrieno Westphal et al. & $\begin{array}{l}\text { Rev Bras Ter Intensiva. } \\
2016 ; 28(3): 220-255\end{array}$ \\
\hline A2 & SCIELO & Brazil/RN & $\begin{array}{l}\text { Structure, process and outcome of organ and } \\
\text { tissue donation for transplantation }{ }^{15}\end{array}$ & $\begin{array}{l}\text { Freire ILS, Vasconcelos QLDAQ, } \\
\text { Torres GV, Araújo EC, Costa IKF, } \\
\text { Melo GSM. }\end{array}$ & $\begin{array}{l}\text { Rev Bras Enferm. } \\
\text { 2015;68(5):555-63. }\end{array}$ \\
\hline A3 & SCIELO & Brazil/SP & $\begin{array}{l}\text { Experiences and expectations of nurses in } \\
\text { care of organ donors and their families }{ }^{16}\end{array}$ & $\begin{array}{l}\text { Moraes ELD, Neves FF, MJD } \\
\text { Santos, Merighi MAB, MCKB } \\
\text { Massarollo. }\end{array}$ & $\begin{array}{l}\text { Rev Esc Enferm USP } \cdot 2015 \\
\text { 49(Esp2):129-135. }\end{array}$ \\
\hline A4 & SCIELO & Brazil/TO & $\begin{array}{l}\text { Nursing and the patient in brain death in the } \\
\text { ICU }^{3}\end{array}$ & Costa CR, Costa LPD, Aguiar N. & $\begin{array}{l}\text { Rev. bioét. (Impr.). 2016; } 24 \text { (2): } \\
\text { 368-73. }\end{array}$ \\
\hline A5 & SCIELO & Brazil/SC & $\begin{array}{l}\text { Organ and tissue transplantation: Nurses' } \\
\text { responsibility }{ }^{4}\end{array}$ & $\begin{array}{l}\text { Mendes KDS, Roza BDA, SDF } \\
\text { Barbosa, Schirmer J, Galvão CM. }\end{array}$ & $\begin{array}{l}\text { Texto Contexto Enferm, } \\
\text { Florianópolis, } 2012 \text { Out-Dez; } \\
\text { 21(4): 945-53. }\end{array}$ \\
\hline A6 & SCIELO & Brazil/SP & $\begin{array}{l}\text { Nurses' experience in the process of organ } \\
\text { and tissue donation for transplantation }{ }^{17}\end{array}$ & $\begin{array}{l}\text { Moraes ELD, Santos MJD, Merighi } \\
\text { MAB, Massarollo MCKB. }\end{array}$ & $\begin{array}{l}\text { Rev. Latino-Am. Enfermagem } \\
\text { mar.-abr. 2014;22(2):226-33. }\end{array}$ \\
\hline A7 & SCIELO & Brazil/PE & $\begin{array}{l}\text { Physiological changes in brain death in } \\
\text { potential donors of organs and tissues for } \\
\text { transplantation }{ }^{18}\end{array}$ & $\begin{array}{l}\text { Freire SG, Izaura Freire LS, Pinto } \\
\text { JTJM,Vasconcelos QLDDAQ, } \\
\text { Torres GDV. }\end{array}$ & $\begin{array}{l}\text { Esc Anna Nery (impr.)2012 out } \\
\text { - dez; } 16 \text { (4):761-766. }\end{array}$ \\
\hline A8 & SCIELO & Brazil/SC & $\begin{array}{l}\text { Guidelines for maintaining multiple organs } \\
\text { in the potential adult donor potential. Part } \\
\text { III. Recommendations specific bodies }{ }^{19}\end{array}$ & Glauco Adrieno Westphal et al. & $\begin{array}{l}\text { Rev Bras Ter Intensiva. 2011; } \\
\text { 23(4):410-425. }\end{array}$ \\
\hline A9 & SCIELO & Brazil/SC & $\begin{array}{l}\text { Managed protocol for treatment of potential } \\
\text { deceased donor reduces incidence of cardiac } \\
\text { arrest before organ transplantation }{ }^{20}\end{array}$ & Glauco Adrieno Westphal et al. & $\begin{array}{l}\text { Rev Bras Ter Intensiva. 2012; } \\
\text { 24(4):334-340. }\end{array}$ \\
\hline
\end{tabular}


Table Continued......

\begin{tabular}{|c|c|c|c|c|c|}
\hline Code & $\begin{array}{l}\text { Data } \\
\text { base }\end{array}$ & $\begin{array}{l}\text { Country/ } \\
\text { State }\end{array}$ & Title & Authors & Journal, Year, Vol, pages \\
\hline A10 & SCIELO & Brazil/CE & $\begin{array}{l}\text { Nursing care for the patient in brain death } \\
\text { and potential organ donor }{ }^{21}\end{array}$ & $\begin{array}{l}\text { Cavalcante LDP, Ramos IC, Araújo } \\
\text { MAM, Alves DDS, Braga VAB. }\end{array}$ & $\begin{array}{l}\text { Acta Paul Enferm. 2014; } \\
\text { 27(6):567-72. }\end{array}$ \\
\hline A11 & SCIELO & Brazil/SC & $\begin{array}{l}\text { Emerging complexity of nursing care when } \\
\text { being in brain death }{ }^{22}\end{array}$ & $\begin{array}{l}\text { Pestana AL, Erdmann AL, Sousa } \\
\text { FGMD. }\end{array}$ & $\begin{array}{l}\text { Esc Anna Nery (impr.)2012 out } \\
\text {-dez; } 16 \text { (4):734-740. }\end{array}$ \\
\hline A12 & SCIELO & Brazil/CE & $\begin{array}{l}\text { Fragility in attention to the potential organ } \\
\text { donor: perception of nurses }{ }^{23}\end{array}$ & $\begin{array}{l}\text { Costa IFD, Netto JJM, Brito } \\
\text { MDCB, Goyanna NF, Santos TCD, } \\
\text { Santos SSD. }\end{array}$ & $\begin{array}{l}\text { Rev. bioética. (Impr.). 2017; } 25 \\
\text { (1): 130-7. }\end{array}$ \\
\hline A13 & SCIELO & Brazil/SP & $\begin{array}{l}\text { Profile of effective donors of the organ and } \\
\text { tissue search service }{ }^{24}\end{array}$ & $\begin{array}{l}\text { Simey de Lima Lopes Rodrigues } \\
\text { et al. }\end{array}$ & $\begin{array}{l}\text { Rev Bras Ter Intensiva. } \\
\text { 2014;26(1):21-27. }\end{array}$ \\
\hline A14 & SCIELO & Brazil/SC & $\begin{array}{l}\text { Guidelines for maintaining multiple organs } \\
\text { in the potential adult donor potential. } \\
\text { Part I. General aspects and hemodynamic } \\
\text { support } 25\end{array}$ & Glauco Adrieno Westphal et al. & $\begin{array}{l}\text { Rev Bras Ter Intensiva. 2011; } \\
\text { 23(3):255-268. }\end{array}$ \\
\hline
\end{tabular}

It was also observed that the highest concentration of publications on this subject is located in the South Region with $43 \%$, followed by the Northeast Region with 29\%, Southeast Region 21\%, North Region $7 \%$ and Central-West Region did not present any study. In relation to the year, we highlight that the year 2012 with the highest number of publications (4) $29 \%$, followed by 2014 with (3) $21 \%, 2015$ (2) $14 \%$, 2016 (2) 14\%, 2011 2) $14 \%$ and 2017 (1) $7 \%$.

Regarding the publications journals, the Brazilian Journal of Intensive Care (CPR) stands out, accounting for $36 \%$ of the

Table 3 Survey design and data collection procedures

\begin{tabular}{ll}
\hline Code & Search delineation \\
\hline A1 & Literature revision \\
A2 & Analytical, longitudinal, and quantitative \\
A3 & Qualitative \\
A4 & Literature revision \\
A5 & Literature revision \\
A6 & Qualitative \\
A7 & Exploratory, descriptive, quantitative \\
A8 & Literature revision \\
A9 & Intervention (quasi-experimental) \\
A10 & Descriptive, exploratory, qualitative \\
A11 & Qualitative \\
A12 & Descriptive, exploratory, qualitative \\
A13 & Quantitative, descriptive, exploratory and retrospective \\
A14 & Literature revision \\
\hline
\end{tabular}

\section{Discussion}

Based on the analysis carried out in this research, two major categories emerged: Nursing care centered on the operationalization of the ME protocol and family approach and nursing care in the maintenance of the organ donor potential.

\section{Nursing care centered on the operationalization of the ME Protocol and family approach}

Based on data analysis, the nursing studies focused on the operationalization of the ME Protocol regarding the notification of all potential donors to CIHDOTT or the Organ Procurement publications used in the study. Regarding the genre of the authors of the articles, it was evident that the majority are males with (84) $56 \%$. Regarding the research design, there were qualitative studies with 9 representing $64 \%$, while the studies with a quantitative delineation represent (5) $36 \%$ of the studied bibliography. Regarding the method of data collection, most of the studies present the interview as the main method of data collection, which can be observed in figure 3 described below Table 3 .

\section{Method of data collection}

Search in database, articles, books, Laws, Decrees and Ordinances

Non-participant observation (check list)

Interview

Analysis of text, themes and interpretations

Descriptive analysis

Interview

check list

Search in database

Form, excel spreadsheet

Interview

Interview

Interview

Analyzing medical records

Search in database

Organization (OPO) or the CNCDO of its State is considered a strong recommendation in the application of the protocol. ${ }^{14}$ In addition, it was observed that for the clinical diagnosis of brain death, there is an important apperceptive coma of known cause, absence of all brain stem reflexes (pupillary, corneal-eyelid, oculus-cephalic, vestibulareyelid, reflex of cough) and apnea. ${ }^{14}$

It was evidenced in the studies analyzed that Law No. 9,434 (4/2/97), known as the Transplantation Law, establishes, in its Article ${ }^{3}$, that "Post-mortem withdrawal of tissues, organs or parts of the human body intended for transplantation or treatment should be preceded by a diagnosis of brain death verified and recorded by two physicians not 
participating in the removal and transplantation teams, using clinical and technological criteria defined by the Federal Medical Council. ${ }^{14}$

It was also observed that according to Decree No. 2668, of June 30,1997 , the diagnosis of brain death must be confirmed by at least two physicians, one of whom is a specialist in neurology. The order of evaluation does not matter, being indifferent whether the first or second examination is done by a specialist in neurology. A later CFM opinion states that a neurosurgeon or a neuropediatrician can replace the specialist in neurology in the diagnosis of brain death. ${ }^{8,14}$ of the analyzed articles, it was identified as important care in the operationalization of the ME Protocol, the minimum interval between the two clinical evaluations necessary for the characterization of brain death varies according to the age group, being from 48 hours to 7 days to 2 months incomplete; from 24 hours to 2 months to 1 year incomplete; from 12 hours to 1 year to 2 years incomplete; of 6 hours if above 2 years. The period of observation between clinical evaluations varies widely across the world. Although there is an interval regulation in Resolution No. 1808 of the CFM, the definition of the time interval for the diagnosis of brain death according to the age group is arbitrary. The time of the second clinical examination is considered time of death. ${ }^{14,15}$

The family should be approached after diagnosis of brain death in order to seek consent from the donation of PD organs. The family approach should be undertaken by the multidisciplinary team, including the nurse. And this is considered an important nursing care in the operationalization of the Protocol, as well as caring for the bereaved family., ${ }^{4,16}$

In order to become a potential effective donor, it is very important to follow some steps: Identification of the potential donor in brain death, notification to the transplant center, evaluation of the potential donor, hemodynamic maintenance donor, family interview, and documentation. Thus, it is evident the need for a multidisciplinary health team to perform the fundamental and necessary care throughout the donation and transplantation process, so that all steps are executed in an agile and adequate manner, observing and respecting social factors, ethical and psychological factors so that the donation is made possible, providing benefits to the recipients, support to donor relatives and to society. ${ }^{3,15,16}$

In order for the patient's assistance in brain death to be satisfactory, it must be done by a multiprofessional team, since, for this assistance to be effective, it is indispensable that there be a professional interrelation, besides the participation and union of the team and communication, given that only in this way will it be possible to achieve productivity and ensure working relationships at all levels of organization. ${ }^{17-20}$

According to the Federal Nursing Council (COFEN), the nursing staff in charge of the organ donation and organ donation process are: planning, executing, administering, supervising and evaluating all nursing procedures provided to the potential organ donor , in accordance with the requirements of the national transplant system, through the implementation of actions, standardization and planning that enable the potentialization of organ and tissue donation and collection to carry out the transplantation, guaranteeing the improvement and positive results for the patients. Nursing care is established by the usual practice, starting with clinical guidelines and protocols performed by professional institutions or associations. ${ }^{4}$
In view of the above, the importance of the nurse professional in the organization of this program is evident, since this professional will provide assistance not focused only on technical procedures, but also on several other dimensions, such as: the physical, biological, psychological, social, spiritual, economic, political, sociological and historical aspects of each patient. , $, 21,22$

It was possible to show in the analyzed publications that all the patients who have their protocol of ME completed and the donation of organs authorized by the relatives becomes a potential donor of organs, however, there are some contraindications that make it impossible to donate organs in an absolute way, such as patients with pathologies such as HIV, neoplasms, hepatitis B and C, sepsis, and serious viral and fungal infections. ${ }^{8,15}$

The essential care in the Encephalic Death and Organ Donation Process is the hemodynamic maintenance of the potential organ donor in an intensive care unit (ICU) performed by trained and qualified professionals with full coverage during the whole ME certification process until the authorization of the family relationship. Therefore, strict control of respiratory, cardiac, hepatic and endocrine functions is important in order to guarantee safety and quality throughout the donation and transplantation process. Early recognition of pathophysiological changes and immediate treatment make it possible to minimize the losses of potential donors due to a lack of poor clinical conditions. ${ }^{14,15,17,23-25}$

\section{Nursing care in maintaining the potential donor organ}

Based on the analysis of the collected data, it was observed that in order to make feasible and preserve the Donor Potential (PD) in ME, it is of paramount importance the physiological maintenance until the removal of the organ is performed. Based on the research, it was identified that the assistance care performed with greater recurrence in PD is related to the maintenance of respiratory, cardiac, endocrine, metabolic functions, hematological, renal and corneal functions. They are cares performed in patients admitted to the ICU to promote the supply of oxygen to the tissues, hemodynamic stabilization, supply and hydroelectrolytic control to the tissues, which can then minimize the loss as well as reduce the functions of organs for transplantation. ${ }^{15-17,25}$

There was a greater recurrence in the studies analyzed of the care related to the maintenance of the donor potential in order to guarantee the effectiveness of organ donation for maintenance and physiological and hemodynamic preservation, and these should be instituted from the beginning to the end of the ME protocol. ${ }^{3,21}$

Initial basic care was performed by the nursing team: evaluation of the medication prescriptions related to the neurological condition, measurement of the vital signs in the 24-hour period, maintenance of body temperature, monitoring of adequate blood pressure, change of decubitus, avoiding pressure injuries , a 30-degree overhead, artificial ventilation and tracheal aspiration to maintain clear airways, maintain calibrated peripheral access, water monitoring, care for corneas, observe and record glycemic and blood clotting values, perform body hygiene, hydration of the corneas, attention to reduce urine output., ${ }^{3,21}$

Regarding the maintenance of the PD regarding renal function, it is used the blood pressure measurement in an invasive way, providing greater stability in the PDs. Maintain reference value of mean blood pressure above $65 \mathrm{~mm} \mathrm{Hg}$ or systolic blood pressure above $90 \mathrm{~mm}$ Hg. ${ }^{19,20,25}$ Of the intervention care to guarantee PD maintenance, 
those related to the physiological changes and complications related to hypotension were identified, obtaining $100 \%$ of the PDs, thus hypothermia 75\%, hypernatremia (hydroelectrolytic imbalance) $62 \%$, DI (Diabetes insipid us) $37 \%$, hyperglycemia $32.3 \%$, infection $(25.0 \%)$ and corneal ulcers (3.1\%). Therefore, the knowledge of the changes facilitates the health team's management to be carried out with the PD and to prevent such impacts to guarantee the quality of the maintenance of the organs and tissues for transplantation. ${ }^{18,24}$ In studies, it was observed that the minimum essential aspects for the maintenance of the potential donor are: to maintain the patient's body temperature in the PD with temperature $>35^{\circ} \mathrm{C}$. Ideally between $36^{\circ} \mathrm{C}$ and $37.5^{\circ} \mathrm{C}$. Check the central temperature. Keeping the environment warm, preventing hypothermia from the beginning of the management of the potential donor. ${ }^{3,14,25}$

In relation to the maintenance of the lungs it was evidenced that it is extremely important to keep the PD monitored with continuous pulse oximetry, to perform arterial blood collection every 6 hours and to perform the chest X-ray every 24 hours, to maintain a high head $30^{\circ}$ and $45^{\circ}$, reposition the bed every 2 hours, aspirate the orotracheal tube when necessary, maintain the cuff pressure of the tracheal tube between 20 and $30 \mathrm{~cm} \mathrm{H}_{2} \mathrm{O}$, perform adequate voiding expansion in potential lung donors. Among the indispensable care are the strict monitoring and oxygen supply to the tissues with saturation above $95 \%$ with mechanical ventilator. The ideal reference values are: $\mathrm{SaO}_{2}$ $\geq 95 \%$ and $\mathrm{PaO}_{2} \geq 80 \mathrm{~mm} \mathrm{Hg}$ or $\mathrm{PaO}_{2}>300 \mathrm{~mm} \mathrm{Hg}$ with $\mathrm{FiO}_{2}$ of $100 \%$ and PEEP of $5 \mathrm{cmH}_{2} \mathrm{O}$ or $\mathrm{PaO}_{2} / \mathrm{FiO}_{2} \geq 300 \mathrm{~mm} \mathrm{Hg}$. 34,19

In the analyzed studies, it was observed that care with the maintenance of the potential donor should include maintenance of the heart with the echocardiography exam, in order to evaluate the conditions of function and morphology of this important organ. Cardiac transplantation is investigated: the left ventricular ejection fraction $>50 \%$; absence of structural changes and contractility; cardiac index $>2.5 \mathrm{~L} / \mathrm{min} / \mathrm{m}^{2}$ and $\mathrm{POAP} \leq 15 \mathrm{~mm} \mathrm{Hg} .{ }^{19}$

Regarding the maintenance of the liver, it is advised to perform periodic biochemical dosing tests every 6 hours, aiming at normalization and parameters for laboratory tests such as gamma glutamil, bilirubin, transaminases, alkaline phosphatase, transferase, INR (International Normalized Ratio) and prothrombin time, creatinine levels every 24 hours, urea, and to maintain serum sodium below $160 \mathrm{mEq} / \mathrm{L} \cdot{ }^{19,25}$

The nursing team engages with all its theoretical and technical framework in all stages of maintenance of the organ donor potential, be it in the monitoring, maintenance of blood pressure and respiratory levels, administration of sedative drugs and vasopressors with strict control for the reduction of infusion volumes based on vital signs monitoring, collection of laboratory tests, referrals for exams, as well as basic nursing care such as: airway aspiration, cuff check, dressings, oral and body hygiene.

\section{Conclusion}

Before the present research was carried out, it was possible to identify the priority care to be implemented in the ME protocol, and after analyzing the publications selected for this study it was possible to highlight how the ME protocol is implemented. In this direction it was possible to highlight the care related to the process that involves the verification, maintenance and donation of organs for transplants. Emphasis was placed on the role of the nurse in the multidisciplinary team in organizing the entire process, as well as ensuring the quality of the execution of the required steps. The success of the application of the ME Protocol is anchored in nursing care and the quality multiprofessional team, in order to guarantee the maintenance of the potential donor. It has also been realized that the family has an important place in the context of the ME Protocol. The family nucleus will determine the start for the capture of the organs through their consent.

Among the challenges encountered is the acceptance of the family members, as well as the qualification of the teams for the implementation and operation of the ME Protocol, which requires the permanent training of the team. This study suggests new research as a focus on care related to the family member's approach in brain death and strategies related to the family member's consent to MES, since this is one of the major causes of non-donation, family refusal. Finally, we highlight the importance of this theme and the qualification of future nurses who will be launched in these contexts of care and application of ME Protocols, in order to contribute to the advancement of the donations and thereby save countless lives waiting in waiting list of transplants, bringing greater quality of life to patients awaiting the long-awaited transplant.

\section{Acknowledgements}

None.

\section{Conflict of interest}

The author declares that there is no conflict of interest.

\section{References}

1. SRM file. Role of nurses in organ and tissue transplantation: an integrative review. Brasilia. 2015.

2. Lima CSP, Batista ACO, Barbosa SFF. Perceptions of the nursing team in the care of the patient in brain death. Rev Eletr. 2013;15(3):780-789.

3. Costa CR, Costa LP, Aguiar N. Nursing and the patient in brain death in the ICU. Rev bioét. 2016;24(2):368-373.

4. Mendes KDS, Roza BA, Barbosa SFF, et al. Organ and tissue transplantation: Nurses' responsibility. Florianópolis. 2012;21(4):945953.

5. Silva ABV, Marcelino CAG. Intensive care nursing. In: Viana RAPP. Transplantation and maintenance of the potential donor in intensive care. São Paulo: Ed Artmed; 2011:504-513.

6. Garcia VD, Haussen SR, Piva MO, et al. The diagnosis of brain death In: Garcia CD, Pereira JD, editors. Manual of donation and transplants. Rio de Janeiro: Elselvier; 2013:69-85.

7. Costa CR, Costa LP, Aguiar N. Nursing and the patient in brain death in the ICU. Rev. bioét. 2016;24(2):368-373.

8. Barboza AP, Garcia VD. Manual of donation and transplants. In: Garcia CD. The donation-transplant process. Rio de Janeiro: Elselvier; 2013:53-68

9. Cavalcante LP, Ramos IC, Araújo MAM, et al. Nursing care for the patient in brain death and potential organ donor. Acta Paul Enferm. 2014; 27(6):567-572.

10. Garcia VD, Bonow FP, Pereira RB, et al. Maintaining the potential donor. In: Garcia CD, Pereira JP, editors. Manual of donation and transplants. Rio de Janeiro: Elselvier; 2013:87-101.

11. Gil AC. How to design research projects. 5th ed. São Paulo: Atlas, 2010 .

12. Minayo MCS. The Challenge of Knowledge: qualitative research in health. 14th ed. São Paulo: Hucitec, 2014 
13. Presidency of the Republic (BR). Law No. 9,610, of February 19, 1998 Alters, updates and consolidates copyright legislation. Official Gazette of the Federative Republic of Brazil. 1998;136(36-E Section 1):3-9.

14. Westphal GA, Valter Duro Garcia, Rafael Lisboa de Souza, et al. Guidelines for evaluation and validation of the potential organ donor in brain death. Rev Bras Ter Intensiva. 2016;28(3):220-255.

15. Freire ILS, Vasconcelos QLDAQ, Torres GV, et al. Structure, process and result of donation of organs and tissues for transplantation. Rev Bras Enferm. 2015;68(5):555-563.

16. Moraes ELD, Neves FF, MJD Santos, et al. Experiences and expectations of nurses in the care of the organ donor and his family. Rev Esc Enferm USP. 2015;49(Esp 2):129-135.

17. Moraes ELD, Santos MJD, Merighi MAB, et al. Nurses' experience in the process of donating organs and tissues for transplantation. Rev Latino Am Nursing. 2014;22(2):226-233.

18. Freire SG, Izaura Freire LS, Pinto JTJM, et al. Physiological changes in brain death in potential donors of organs and tissues for transplantation. Esc Anna Nery. 2012;16(4):761-766.

19. Westphal GA, Milton Caldeira Filho, Kalinca Daberkow Vieira, et al. Guidelines for maintaining multiple organs in the potential adult donor potential. Part III. Specific body recommendations. Rev Bras Ter Intensiva. 2011;23(4):410-425
20. Westphal GA, Zaclikevis VR, Kalinca Daberkow Vieira, et al. Managed protocol for treatment of the deceased potential donor reduces the incidence of cardiac arrest before organ transplantation. Rev Bras Ter Intensiva. 2012;24(4):334-340.

21. Cavalcante LDP, Ramos IC, Araújo MAM, et al. Nursing care for the patient in brain death and potential organ donor. Acta Paul Enferm. 2014;27(6):567-572.

22. Pestana AL, Erdmann AL, Sousa FGMD. Emerging the complexity of nursing care when being in brain death. Esc Anna Nery 2012;16(4):734 740 .

23. Costa IFD, Netto JJMN, Brito MDCB, et al. Fragility in the attention to the potential organ donor: nurses' perception. Rev bioét. 2017;25(1):130-137.

24. Rodrigues SLL, Jose Ben Hur de Escobar FN, Luiz Antonio CS, et al. Profile of effective donors of the organ and tissue search service. Rev Bras Ter Intensiva. 2014;26(1): 21-27.

25. Westphal GA, Milton Caldeira Filho, Kalinca DV, et al. Guidelines for maintaining multiple organs in the potential adult donor potential. Part I. General aspects and hemodynamic support. Rev Bras Ter Intensiva. 2014;26(1):21-27. 